\title{
Pooled Data Analysis of Tourism Industry in Special Region of Yogyakarta
}

\author{
Bimo Harnaji \\ Management Department \\ Janabadra University \\ Yogyakarta, Indonesia \\ bimo@janabadra.ac.id
}

\author{
Rini Raharti \\ Economics Department \\ Janabadra University \\ Yogyakarta, Indonesia \\ riniraharti@janabadra.ac.id
}

\author{
Titop Dwiwinarno \\ Management Department \\ Janabadra University \\ Yogyakarta, Indonesia \\ titop@janabadra.ac.id
}

\begin{abstract}
Tourism industry is one of sectors which is relied by government as regional acceptance post, therefore, the government of Special Region of Yogyakarta is requested to be able to dig and manage tourism potencies that it has. Tourism industry can be developed as an effort to get source of funds through new innovation in having effort to finance regional expense through retribution obtained from every tourism attraction in each region. The objective of this research is to estimate tourism industry, which is in this case, they are variables of the number of tourism attractions, the number of hotels and GRDP as independent variables towards variable of tourism retribution as dependent variable with the objects of research are all areas of districts/city in Special Region of Yogyakarta. Data used in this research were data of time series which in this case, they were from researches is 2010-2018 and data of cross section which were data of tourism industry for all areas of districts/city in Special Region of Yogyakarta. The analysis method used was analysis of pooled data which combine data of time series and cross section, and in testing, it used software of Eviews 9.0. This research model is able to describe variables which influence tourism retribution as much as $91,63 \%$. It can be proved on testing fixed effect on $\mathrm{R2}$ as much as 0.916325 in meaning that the independent variables, the number of tourism attractions, the number of hotels and GRDP, are able to desribe the dependent variabel, tourism retribution, as much as $91,63 \%$.
\end{abstract}

Keywords: tourism industry, tourism attraction, the number of hotel, GRDP, tourism retribution

\section{INTRODUCTION}

Tourism is one of service industry activities that become Indonesia's mainstay in improving foreign exchange in sector of non oil and gas. In essence, natural wealth, art and culture, and diversity of tourism potencies such as various facilities owned by the region can become basic capital of development and sustainable tourism development. The development of tourism has important role as development and economic growth in creating healthy and dinamic condition through managing business activities and tourism in region [1,2].

Tourism industry is one of fields that has a big opportunity as a factor to promote national economy today [3]. This sector is expected to be able to play a role as the mainstay source of foreign exchange income, and a field that is able to create a lot of jobs as well as improve investment. Efforts conducted by government in increasing tourism field are makes plans and various policies, one of its policies is by digging, making inventory and advancing every tourism attraction existed as a magnetism for tourists. Tourism field has many potencies that can be utilized, one of them is as an effort to improve Own Source Revenue by taking retribution of tourism attraction $[4,5]$.

Special Region of Yogyakarta is an region that has various tourism places, either natural tourism, artificial tourism or historical tourism. They have thier own magnitism compared to other regions. Tourism industry in Special Region of Yogyakarta is expected to be able to give sufficient income contribution for regional government because the number of tourists visiting to Yogyakarta are getting up. Therefore, researcher proposes the research title about tourism industry in Special Region of Yogyakarta using approach of pooled data The problems in this research can be formulated as follows (i) is there any influence of the number of tourism attractions towards tourism retribution in Special Region of Yogyakarta?; (ii) is there any influence of the number of hotels towards tourism retribution in Special Region of Yogyakarta?; (iii) Is there any influence of GRDP towards tourism retribution in Special Region of Yogyakarta?; (iv) Is there any influnce simultaneously among the number of tourism attractions, the number of hotels and GRDP towards tourism retribution in Special Region of Yogyakarta?. While the objectives of the research are (i) estimating the influence of the number of tourism attractions towards tourism retribution in Special Region of Yogyakarta; (ii) estimating the influence of the number of hotels towards tourism retribution in Special region of Yogyakarta; (iii) estimating the influence of GRDP towards tourism retribution in Special Region of Yogyakarta; (iv) estimating simultaneously the number of tourism attractions, the number of hotels, GRDP towards tourism retribution in Special Region of Yogyakarta. The researches about tourism industries with analysis of panel data have not much been carried out, therefore in this research, it is more emphasized on the approach of panel data for tourism industry in Special Region of Yogyakarta.

\section{LITERATURE REVIEW}

\section{A. Tourism History}

Tourism has been known in the world since prehistoric times, however the definition of tourism at that time is not similar today (modern time). Long time ago, the world nations such as Sumeria, Phoenisia, until Roman, already travelled, but the aim was for trading, improving knowledge of living science, or political science. Then, after modernization is widespread all over the world, especially after revolution of 
industry in England, then travellers are come up alternately to do travelling as we know today [6].

Whereas in Indonesia itself, tourism has been known since kingdom era which dominated archipelago area, although at that time they were concerned for dominating each other, however it could not be undeniable that there was cultural exchange among areas. Indonesia modern tourism has been known since Dutch colonialism era in Indonesia. Through Vereeneging Toesristen Verker (VTV), it was an institution or official tourist bureau. The position of VTV besides as a tourism institution also acted as tour operator or travel agent. At that time, tourism institution was founded by Dutch just prioritizing for only white tourists, while for natives themselves were given limitation as it was done for other sectors. After independence, Indonesia tourism, little by little, showed enhancement. From the period of Repelita I to Repelita IV tourist in Indonesia were getting up drastically, even exceeded the target, that were 11.626.000 tourists which was in the beginning that were targeted only 3.000.000 people.

The term of tourism was firstly introduced by two cultural practitioners in 1960's, by Moh. Yamin and Prijono. Both of them gave idea to government to change the term of tour in order to be appropriate to special language of archipelago [7].

\section{B. Tourism}

Defines tourism as an economical activity which has to be seen from two sides namely demand side and supply side $[8,9]$. Furthermore, it is stated that the successfulness in developing tourism in an area depends on ability of designer in integrating both sides equally into a tourism development plan. From the demand side, for instance, it has to be identified potencial market segments for the area concerned and the main attraction factors for area of tourism destination. This description shows stategical value of tourism plan, therefore tourism can give prior benefit for public welfare [10].

According to [11], tourism is a tour activity done for a while from original residence to destination area with the reason not to stay or work but only for having fun, fulfilling his/her curiosity, spending his/her leisure time or holiday as well as other objectives. However, basically, tourism is an indication of people movement temporaly and spontaneously in order to fulfill needs and curiosity [12]. Tourism attraction is a place or natural condition having tourism source that is built or developed so that it has attractions and makes tourists visit $[13,14]$.

According to [15], an area becomes good tourism destination, it has to develop three things so that it attracts to be visited, namely:

- Something to see, it means that there is something to see, in this case the tourism attraction differs from other places (having own uniquiness). Besides that, it also needs to concern about tourism attractions that become as entertainment when people visit.
- Something to buy, there is something interesting, something special to buy to become souvenir to bring home so that in that area, there are facilities to do shopping that provide souvenir and other handicrafts as well and it has to be supported by other facilities such as money changer and bank.

- Something to do, there are activities that can be done in that place which can make vistitor feel at home.

From the description above, it can be concluded that a good and interesting tourism place to be visited must have natural beauty and also have uniquiness and attraction to be visited and also supported other facilities to be enjoyed at the time the visitors visit [16].

\section{Tourist}

Tourist is a person motivated by something or various needs to do travel and stop by outside his/her residence for more than 24 hours with no aim to do job [17]. Person who is called tourist, based on constitution No. 9, year of 1990 about tourism is tour done voluntary, tour to other place outside his/her area/country of residence, temporary and staying at least one night, not for work, the main purpose is to have a leisure, holiday, health, religious and do sport, business visit, family visit, assignment and attend conference [18,19].

\section{Gross Regional Domestic Product (GRDP)}

The important indicator to be able to know economical condition of a region in certain period is by using data of Gross Regional Domestic Product (GRDP), it can use on the basis of price applied or constant price. According to [20], economic growth is the increasing of per capita output in long term, the emphasize is on three aspects, namely process, percapita output, as well as long term. Economic growth is a process, not only shortly economic picture. Regional development as well as sectoral development must be implemented in line so that sectoral development in regions is able to functionate in accordance with their potencies as well as region priorities. Gross Regional Domestic Product (GRDP) is the number of additional value that is produced for all business areas and services in an area, applies the number of all good values and end services produced by all economic unit, GRDP itself can be interpreted as the number of additional values that are produced by all business units or the number of all good values and services by all economic unit in an area [21].

Economic growth is the development of public welfare which is measured with the magnitude of pre-capita Gross Regional Domestic Product (per-capita GRDP) growth [22]. The higher the value of GRDP in an area, thus it shows the higher level of economic growth as well as it reflects that the region experiences progress in its economy. Basically, economic growth in a region can occur when endogenous determinants (factors inside the region) or exogenous (factors outside the region) are involved and combined. The approach 
usually used in describing regional growth is by using models of macro economy [23].

\section{METHOD}

\section{A. Type and Data Resource}

Data used were secondary data with time span of 14 years, from 2010 to 2018 for districts/city in Special Region of Yogyakarta. The secondary data that were collected involving the data of the number of tourism attractions, the number of hotels, GRDP and total of tourism retributions, those data were published by publication of Government Tourism Office and Central Bureau Statistics of Special Region of Yogyakarta.

\section{B. Regression Model of Pooled Data}

This research used quantitative approach with method of pooled data, namely combining data of time series and cross section. This analysis described relation among dependent variable, tourism retribution and independent variables, the number of tourism attractions, the number of hotels and GRDP. The model made in this research used equation of function as follows:

Tourism retribution $=\mathrm{F}$ (the number of tourism attractions, the number of hotels, GRDP)

Then the equation above put in the form of equation model of pooled data with logarithm as follows :

$$
L Y=\alpha_{0}+\beta_{1} L_{1}+\beta_{2} L_{2}+\beta_{3} L_{3}+\mu
$$

in which:

$\mathrm{Y}=$ Tourism Retribution

$\mathrm{LX}_{1}=$ The number of tourism attractions

$\mathrm{LX}_{2}=$ The number of hotels

$\mathrm{LX}_{3}=\mathrm{GRDP}$

$\alpha \quad=$ constant

$\beta=$ coefficient

$\pi=$ error term

Then regression equation was analyzed using 3 method, namely:

- Pooled Least Square (PLS) or Common Effect Model (CEM)

This method is the main method that is used with estimating pool data by combining data of cross section and time series without seeing the difference between time and individu that will obtain a lot of observation. Basic assumption on the approach of PLS are that values of intercept and slope between unit of cross section and time series are the same.

\section{- $\quad$ Fixed Effect Model (FEM)}

Fixed effect model (FEM) is simple method to know the difference between object and constant among objects. It is assumed that intercept among individu are different but the slope are still the same among individu.

- Random Effect Model (REM)

According to [24] describes that dummy variable is put in into model of random effect in order to represent our nescience about the real model. But this brings the consequences of reduced freedom degree which in turn reducing parameter efficiency. This problem can be solved by using error term which is known as method of random effect.

\section{Model Selection}

To test compatibility and goodness of model from three models on model estimation technique with pooled data using Chow test and Hausman test.

\section{- Chow test}

Chow test is called as testing F-statistics that test is to choose model used to compare model of common effect with fixed effect. When value of chow statistic (F-stat) of test result is bigger than F-table, thus it is enough to do rejection towards zero hypothesis so that model used is model of fixed effect.

\section{- Hausman test}

Hausman test is used to select the most appropriate model, whether the most appropriate model uses fixed effect or random effect. Determination result of value of Hausman test is gained by comparing value of chi-square statistic with critical value of chi-square, degree of freedom (df) used is as many as $\mathrm{k}$ (number of independent variables).

The hypothesis is as follows:

If statistics value of Hausman test is bigger than its critical value, thus it rejects Ho and the model used is model of fixed effect, if statistics value of Hausman test is smaller than the ctitical value, thus it accepts Ho and the model used is random effect.

\section{RESULT AND DISCUSSION}

\section{A. Model Estimation}

Testing estimation model is done to find out the suitable model used in analysis of econometrics model. Model selection in this research is conducted by using regression analysis of pooled data by using three models, namely Common Effect Model, Fixed Effect Model and Random Effect Model. To choose the best model between Common Effect Model and Fixed Effect Model is used Chow Test, whereas to choose between Fixed Effect Model and Random Effect Model is used Hausman Test.

\section{- Chow Test}

The result of significance test which is comparation between model of Common Effect and Fixed Effect can be looked at as follows: 
TABLE 1: TEST RESULT OF REDUNDANT FIXED EFFECTS-LIKELIHOOD RATIO

\begin{tabular}{|l|c|c|c|}
\hline \multicolumn{1}{|c|}{ Effects Test } & Statistic & df & Prob. \\
\hline Cross-section F & 11.892102 & $(4,37)$ & 0.0000 \\
\hline Cross-section Chi-square & 37.198929 & 4 & 0.0000 \\
\hline
\end{tabular}

Source: secondary data processed, 2020

Result of Chow Test can be known that cross section $\mathrm{F}$ is as much as 11.892102 with probability of 0.0000 and it is significant on $\alpha=5 \%$. Because probability of cross section $\mathrm{F}$ is significant on $\alpha=5 \%$, therefore decision making of model used is Fixed Effect.

\section{- Hausman Test}

The result of significance test which is comparation between models of Fixed Effect and Random Effect can be seen as follows:

TABLE 2: RESULT OF CORRELATED RANDOM EFFECTS-HAUSMAN TEST

\begin{tabular}{|c|c|c|c|}
\hline Test Summary & Chi-Sq. Statistic & Chi-Sq. df & Prob. \\
\hline & 12.2988 & & 0.006 \\
\hline Cross-section random & 45 & 3 & 4 \\
\hline
\end{tabular}

Source: secondary data processed, 2020

From that test result can be known that cross section random is as much as 12.298845 with probability as much as 0.0000 and it is significant on $\alpha=5 \%$. Because probability of cross section random is significant on $\alpha=5 \%$, therefore the decision making of the model used is Fixed Effect.

\section{B. Classical Assumption Test}

Classical assumption test in this research involves normality test, multicollonearity test and heteroscedasticity test.

\section{- Normality Test}

Normality test is to test whether in the regression model, independent variables and dependent variabel are distributed normally or not. Decising making with Jarque-Bera Test or J$\mathrm{B}$ Test which is value of $>5 \%$, thus those variables are distributed normally. Based on normality test on probability as much as 0.759222 shows that probability is $>5 \%$, therefore it can be concluded that the data are distributed normally.

\section{- Multicollinearity Test}

Multicollinearity test is to test whether the regression model occurs correlation among independent variables or not. According to [25] if coefficient of corelation among independent variables is more than 0.8 , so it can be concluded that the model has multicollinearity problem. Vice versa, if correlation coefficient among variables is less than 0.8 , thus the model is free from multicollinearity problem. Based on the test result of multicollinearity, all correlation coefficients are less than 0.8 , therefore it can be concluded that the model is free from problem of multicollinearity.

\section{- Heteroscedasticity Test}

Heteroscedasticity test is to test whether in the regression model, it occurs varian inequality from residual of one observation to other observations. Based on result of heteroscedasticity test with Breusch Pagan LM above, it shows the probability more than 0.05 . It means that there is no heteroscedasticity in this model.

\section{Statistical Analysis}

Based on the selection of model done, thus model of fixed effect is selected to become the best model to estimate.

- Test of $\left(\mathrm{R}^{2}\right)$

Coefficient of determination $\left(\mathrm{R}^{2}\right)$ is as much as 0.916325 , it means that the independent variables, namely the number of tourism attractions, the number of hotels and GRDP are able to describe the dependent variable, that is tourism retribution as much as $97.70 \%$. While the rest $2.30 \%$ is described by other variables outside the model

\section{- F test}

F test is used to know whether variables together give effect to the dependent variable or not. Based on the test result, it is obtained F-statistic as much as 36.82982 with probability F-statistic as much as $0.000000<\alpha 5 \%$, which means Ho is rejected. The independent variables, which are the number of tourism attractions, the number of hotels and GRDP together have significant effect towards the dependent variable, that is tourism retribution.

- $\mathrm{T}$ test

T test is used to know whether or not there is the effect of the dependent variable towards the independent variables individually and it is considered that the dependent variable is more constant. Based on test result above, thus the decision making is as follows:

a. Testing towards $\mathrm{LX}_{1}$ variable

Based on result of data calculation uses program of Eviews 9, thus it is obtained the result that significant value is as much as 0.0011 , which means that $\mathrm{LX}_{1}$ variable has significant effect towards $\mathrm{Y}$ because significant value is smaller than 0.05 with positive direction of relation.

b. Testing towards $\mathrm{LX}_{2}$ variable

Based on result of data calculation uses program of Eviews 9, thus it is obtained the result that significant value is as much as 0.0112 , which means that $\mathrm{LX}_{2}$ has significant effect towards $\mathrm{Y}$ because significant value is smaller than 0.05 with positive direction of relation.

c. Testing towards $\mathrm{LX}_{3}$ variable

Based on result of data calculation uses program of Eviews 9, thus it is obtained the result that significant value is as much as 0.0005 , which means that $\mathrm{LX}_{3}$ variable has significant effect towards $\mathrm{Y}$ because significant value is smaller than 0.05 with positive direction of relation. 


\section{Result Interpretation:}

By fixed effect model, hence it is obtained regression equation as follows:

$$
\begin{aligned}
& \mathrm{LY}=1.104262+0.912079 \mathrm{LX}_{1}+1.690465 \mathrm{LX}_{2}+0.626479 \\
& \quad \mathrm{LX} 3
\end{aligned}
$$

Based on regression equation, hence it can be described that regression coefficient value of the number of tourism attractions as much as 0.912079 shows that when the number of tourism attractions increase as many as 1 unit so tourism restribution is getting up as much as 0.912079 rupiah if other independent variables are in constant condition. The positive coefficient regression means the higher the percentage value of the number of tourism attractions, thus tourism retribution is increasing.

Regression coefficient value of population density as much as 1.690465 shows that when the number of hotels increase as many as 1 unit, hence tourism restribution is increasing as much as 1.690465 rupiah if other independent variables are in stable condition The positive regression coefficient means the higher the number of hotels, thus tourism restribution is going up.

Based on the regression equation, it can be described that regression coefficient value of GRDP as much as 0.626479 shows that when GRDP is up as many as 1 unit, hence tourism restribution is increasing as much as 0.626479 rupiah if other independent variables are in stable condition. The positive coefficient regression means the higher GRDP the higher the tourism retribution.

\section{E. Discussion}

The effect of the number of tourism attractions towards retribution income in 5 districts/city in Special Region of Yogyakarta. Based on analysis result can be explained that variable of the number of tourism attractions has positive and significat influence with coefficient value as much as 0.912079 towards tourism restribution of districts/city in Special Region of Yogyakarta from 2010 to 2018. It shows that if tourism attraction in a region has increasing as many as 1 unit of tourism attractions, thus it will increase retribution income in Special Region of Yogyakarta as much as 0.912079 rupiah. This result is in accordance to research hypothesis statement that there is positive effect towards tourism retribution income which is seen from the number of tourism attractions of districts/city in Special Region of Yogyakarta during 2010 until 2018. The same statement is also said by [26] finding that there is an effect of the number of tourism attractions towards tourism restribution income. From the regression calculation result, as shown on equation above, shows consistency towards theory that the number of tourism attractions give positive sign. This is in line with the theory mentioning that the existance of the number of tourism attractions can increase regional income of tourism sector in the Special Region of Yogyakarta, either through regional tax or regional retribution.
The effect of the number of hotels towards retribution income in 5 districts/city in Special Region of Yogyakarta. Based on analysis result, it can be described that variable of the number of hotels with coefficient value as much as 1.690465 is significant towards tourism restribution income of districts/city in Special Region of Yogyakarta from 2010 to 2018. It shows that if the number of hotels is increasing as many as 1 unit, hence it will develop retribution income of districts/city in Special Region of Yogyakarta as much as 1.690465 rupiah. This result is in accordance to the research hypothesis stating that there is positive effect of the number of 5 districts/city restribution in Special Region of Yogyakarta.

The effect of GRDP towards retribution income in 5 districts/city in the Special Region of Yogyakarta. Based on analysis result, it can be described that variable of GRDP with coefficient value as much as 0.626479 is significant towards tourism restribution income of districts/city in Special Region of Yogyakarta from 2010 to 2018. It shows that if GRDP is getting up as many as 1, thus it will improve retibution income of districs/city in Special Region of Yogyakarta as much as 0.626479 rupiah. This result is suitable with the research hypothesis stating that there is positive effect of the number of 5 districts/city retribution in Special Region of Yogyakarta.

The influence of the number of tourism attractions, the number of hotels, and GRDP towards retribution of districts/city in Special Region of Yogyakarta. Based on the regression result of research, variables of the number of tourism attraction, the number of hotels and GRDP have influence together towards retribution of districts/city in Special Region of Yogyakarta from 2010 to 2018. It is proved with all variables used have significantly influence, namely the number of tourism attractions, the number of hotels and GRDP. Therefore, it can be concluded that variables of the number of tourism attractios, the number of hotels and GRDP together have influence towards tourism restribution income of 5 districs/city in Special Region of Yogyakarta from 2010 to 2018 .

\section{CONCLUSION}

BASED ON THE RESEARCh RESUlt AND Discussion, Hence It CAN Be Concluded As Follows: (I) Variable OF THE Number Of TOURISM ATtRaCtion Has Positive AND SIGNIFICANT INFLUENCE TOWARDS RESTRIBUTION INCOME OF DisTRICTS/CITY IN SPECIAL REgION OF YOGYAKARTA; (II) VARIable Of THE Number Of Hotels Has Positive AND SIGNIFICANT INFLUENCE TOWARDS RETRIBUTION INCOME OF Districts/CITY IN SPECIAL REGION OF YOGYAKARTA; (III) VARIABLE OF GRDP PER DISTRICT/CITY IN CENTRAL JAVA HAS Positive AND SIGNIFICANT INFLUENCE TOWARDS RETRIBUTION INCOME OF DISTRICTS/CITY IN SPECIAL REGION OF YogyaKarta; (Iv) Variable OF THE Number OF TOURISM ATTRACTIONS, THE NUMBER OF HOTELS AND GRDP TOGETHER HAVE Positive AND SignifiCANT INFLUENCE TOWARDS ECONOMIC GROWTH OF DISTRICTS/CITY IN SPECIAL REGION OF YOGYAKARTA. 
BASED ON THE RESEARCH TOWARDS REGIONAL INCOME OF TOURISM SECTOR IN SPECIAL REGION OF YOGYAKARTA, THEREFORE IT CAN BE DELIVERED SUGGESTIONS AS FOLLOWS: (I) THE NUMBER OF TOURISM ATTRACTIONS IN SPECIAL REGION OF YOGYAKARTA REALLY INFLUENCE THE AMOUNT OF RETRIBUTION OBTAINED IN REGIONAL GOVERNMENT. IT IS IMPORTANT TO BE CONCERNED BY PROVINCE GOVERNMENT OF SPECIAL REGION OF YOGYAKARTA IN ORDER TO FURTHER IMPROVE ITS FACILITIES AND MAINTAIN TOURISM ATTRACTIONS TO BE BETTER AS WELL AS CAN PROMOTE TOURISM ATTRACTIONS THAT HAVE NOT BEEN PUBLISHED GLOBALLY BY MAKING WEBSITE OR OTHER PUBLICATION TOOLS SO THAT IT CAN DRAW ATTENTION OF TOURISTS FROM OTHER AREA OR EVEN INTERNATIONAL TOURISTS; (II) ALL REGIONS OF DISTRICTS/CITY IN SPECIAL REGION OF YOGYAKARTA HAS BIG POTENCIES TO UTILIZE HOTEL FACILITIES AND LODGEMENT IN ORDER TO ATTRACT TOURISTS. WITH VARIOUS KINDS OF QUALITY IMPROVEMENT OF HOTELS AND LODGMENTS, THUS CONTRIBUTION OF ACCOMODATION FACTORS (LODGMENT, HOTEL) WILL BE MUCH MORE TOWARDS RETRIBUTION. A TOURISM ATTRACTION IS ABLE TO BE A VERY SUPPORTIVE WORK AREA IF IT IS MANAGED WELL. BY MANAGING FACILITIES OF TOURISM ATTRACTIONS WELL, HENCE VISITORS OF TOURISM ATTRACTIONS WILL BE MORE AND MORE. FROM THE INCREASED PRODUCTION, THUS GRDP WILL INCREASE AS WELL AND IS ABLE TO MAKE THE TOURISM ATTRACTIONS MANAGED WELL FOR LONG TERM BECAUSE IT ALSO IMPROVES THE AMOUT OF REGIONAL GOVERNMENT INCOME.

\section{ACKNOWLEDGMENT}

Thanks for comments and suggestions from reviewers and audiences of The 3rd International Conference on Banking, Accounting, Management, and Economics (ICOBAME) 2020.

\section{REFERENCES}

[1] Jaafar, M., Bakri, N. M., \& Rasoolimanesh, S. M. (2015). Local Community and Tourism Development: A Study of Rural Mountainous Destinations. Modern Applied Science; Vol. 9, No. 8; 2015

[2] Richards, G.: Cultural tourism: A review of recent research and trends. J. Hosp. Tour. Manag.Vol. 36. pp. 12-21 (2018)

[3] Guccio, C., Mazza, I., Mignosa, A and Rizzo, I.: A round trip on decentralization in the tourism sector. Ann. Tour. Res. Vol. 72. pp. 140 155 (2018)

[4] Suparwoko, 2012. Pengembangan Ekonomi Kreatif Sebagai Penggerak Industri Pariwisata Kabupaten Purworejo, Jawa Tengah. Ekonomi_Kreatif_Sebagai_Penggerak_Industri_Pariwisata_Kabupaten_ Purworejo_Jawa_Tengah

[5] Azam, M., Alam, M, M and Hafeez, M, H.: Effect of tourism on environmental pollution: Further evidence from Malaysia, Singapore and Thailand. J. Clean. Prod. Vol. 190. pp. 330-338 (2018)

[6] Okafor, L, E., Khalid, U and Then, T.: Common unofficial language, development andinternational tourism. Tour. Manag. Vol. 67. pp. 127 138 (2018)

[7] Pendit, S. Nyoman.1990. Inventarisasi Industri Pariwisata Indonesia, Indonesia dalam Era Globalisasi, Jakarta. : Bank Summa.

[8] Ismayanti. 2010. Pengantar Pariwisata. Jakarta : Grasindo

[9] Dutt, C, S., Harvey, W, S and Shaw, G.: The missing voices in the perceptions of tourism: The neglect of expatriates. Tour. Manag. Perspect. Vol. 26. pp. 193-202 (2018)
[10] Huber, D., Milne, S and Hyde, K, F.: Constraints and facilitators for senior tourism. Tour.Manag. Perspect. Vol. 27. pp. 55-67 (2018)

[11] Meyers, Koen. 2009. Pengertian Pariwisata, Jakarta: Unesco Office.

[12] A. Vatn, An institutional analysis of payments for environmental services, Ecol. Econ. 69 (2010) 1245-1252.

[13] Salih T. Katircioglu, (2009). Revisiting the tourism-led-growth hypothesis for Turkey using the bounds test and Johansen approach for cointegration, Tourism Management 30: 17-20

[14] P.A. Whitelaw, B.E.M. King, D. Tolkach, Protected areas, conservation and tourism - financing the sustainable dream, J. Sustain. Tour. 22 (2014) 584-603

[15] Yoeti, Oka A. 1988. Pengantar Ilmu Pariwisata. Bandung: PT. Angkasa

[16] N. Beaumont \& Dredge, , "Local Tourism Governance: A Comparison of Three Network Approach. Journal of Sustainable Tourism”, (2010) 7 28

[17] Fandeli, C. dkk. 2000. Pengusahaan Ekowisata. Yogyakarta: Fakultas Kehutanan Universitas Gadjah Mada.

[18] B. Bramwell, \& Lane, B. " Critical Research on The Governance of Tourism and Sustainability. Journal of Sustainable Tourism", (2011) 411-421.

[19] D. Dredge \& Whitford, M. "Event tourism governance and the public sphere. Journal of Sustainable Tourism" Vol. 19, Nos. 4-5, (2011) 479499.

[20] Sukirno, Sadono.2005. Mikro Ekonomi, Teori Pengantar. Penerbit PT. Raja Grafindo Persada, Jakarta.

[21] Badan Pusat Statistik Daerah Istimewa Yogyakarta. 2019. DIY Dalam Angka 2019. Yogyakarta: Badan Pusat Statistik Provinsi DIY

[22] Zaris, Roeslan. 1987.Prespektif Daerah dalam Pembangunan Nasional JakartaLPFE UI

[23] Afrizal, Fitrah. 2013. Analisis Pengaruh Tingkat Investasi, Belanja Pemerintah Dan Tenaga Kerja Terhadap PDRB Di Provinsi Sulawesi Selatan Tahun 2001-2011, Universitas Hasanudin.

[24] Agus, Widarjono. 2013. Ekonometrika Pengantar Dan Aplikasinya Ekonosia. Jakarta.

[25] Gujarati, Damodar. 2003. Basic Econometrics. New York : Mc Graw Hill,.

[26] Qadarrochman, Nasrul. 2010. "Analisis Penerimaan Daerah dari Sektor Pariwisata Di Kota Semarang dan Faktor-Faktor yang Mempengaruhinya (skripsi)". Semarang : Universitas Diponogoro.[2] M. D. Fetters and D. Freshwater, "Publishing a methodological mixed 